\title{
Allogeneic Stem Cell Transplant Recipient
}

National Cancer Institute

\section{Source}

National Cancer Institute. Allogeneic Stem Cell Transplant Recipient. NCI Thesaurus.

Code C159662.

A person receiving an allogeneic stem cell transplant. 